\title{
ANALYSIS OF ACCIDENTS AT THE QUAYSIDE OPERATIONS IN THE TURKISH PORTS
}

\author{
E. Gül Emecen Kara \\ Assistant Professor, Dr.Istanbul University, Engineering Faculty, Department of Maritime Transport Management \\ Engineering, Istanbul, Turkey
}

\begin{abstract}
Ports have an important role in the economics of countries. Ports are a dynamic system where many operations carried out. Port operations pose various risks depending on type of operation and type of handling cargo. Most of accidents occurring in the port take place during quayside operations. In this context, this study aims to analysis ofaccidents occurring during quayside operations with respect to terminal types in the Turkish ports. For this purpose, quayside operation characteristics and the risks that may occur during quayside operations depending on handling cargo types are examined generally and types of accidents and their effects are analyzed between 2009 and 2015 in the Turkish ports, according to terminal types.
\end{abstract}

Keywords: Quayside Operation, Operational Risk, Safety, Accident, Sea Port

\section{INTRODUCTION}

Seaports are the essential components of maritime shipping and they have an important role in the economics of countries. It fulfills functions of the transshipment and the temporary storage of goods regularly and meet the need of ships. Seaports may serve one or more type of cargo. Unit of seaport that serves types of a special cargo and ship is called terminal. Terminals are classified as bulk, general cargo, container and Ro-Ro. They have different types of handling equipment and the terminal layouts. Therefore, operations carried out at these terminals different from each other. Port operations generally divided into two subsystems: quayside operation and landside operation. Quayside operation covers the berthing and mooring operations, loading/unloading operations and cargo transport operations in the berth. Landside operations comprise yard operations and hinterland operations.

These operations give rise to various risks based on the characteristics of equipment used in the handling of cargo, the nature of operation and types of cargo. Many operations are carried out simultaneously and there are many moving handling machines in the terminal area and ships in the mooring area [1]. Handling machines and terminal workers work in the same environment. Ports work every day and throughout 24 hours. Operations arecarried out as quickly as possible, because time is important for ports. Therefore, there are always high-risk at the port operations. According to Health and Safety Executive (HSE),ports are a potentially high-risk industry to work in. Occupational accidents occurring in the ports compose an important part of all work-related accidents [2].

Most of accidents occur during quayside operations in ports. The accident occurring in the ports threatens the human and environmental health, in addition to it causes commercial losses [1]. At the same time, it is one of the most important factors affecting the efficiency of terminal operations [3]. This study aims to analysis of accidents occurring during quayside operations with respect to terminal types in the Turkish ports. Firstly, for this purpose, quayside operation characteristics and the risks that may occur during quayside operations depending on handling cargo types are examined generally. And later types of accidents and their effects are analyzed by grouped into types of quayside operation between 2009 and 2015 in the Turkish ports, according to terminal types. Consequently, quayside operations safety is discussed.

\section{THE QUAYSIDE OPERATIONS AND THE}

\section{RISKS}

Quayside operations comprise berthing and mooring operations, loading / discharging and shifting operations, lashing/unlashing operations and transporting of cargo in quay. Used handling equipment and the risks occurring during operations different from each other according to type of terminal.

Handling operations of container are carried out at the container terminal. The loading and unloading of container are performed by Quay Cranes (QC). There are two types QC: Mobil Harbor Crane (MHC) and Gantry Crane (SSC ship to shore crane). SSC that is specifically designed for container handling is fixed quay crane. MHC may use also for handling other cargo types and may go to any place on the quay. In addition to, terminal transport vehicles are used to transport containers between container yard and the berth. The most common types of these vehicles are Yard Towing Trucks (YTT), Multi Trailers, and Straddle Carriers (SC) $[1,4]$. 
Handling operations of bulk cargo are carried out at the bulk terminal. There are two types of bulk terminal as liquid and dry. In dry bulk terminals are handled bulk cargoes such as coal, iron ore, cereals. Grabs (mechanical grabs and hydraulic grabs), conveyors (screw conveyor, belt conveyor and pneumatic conveyor) and stacker are used for both loading and discharging of bulk cargoes. Same bulk carriers have own handling equipment. In liquid bulk terminals are handled petroleum products, oil, chemicals. Pipelines and pumps are used as handling equipment.

Mixed part loads such as glazing, roll paper and flour are handled at the general cargo terminal. Used handling equipment are quay crane and palette, slings which is fixed quay crane.

In addition to these terminals, Ro-Ro terminal services RoRo ships and passenger. Ro-Ro bridges and vessel ramps are used for operations.

The operational risks in the quayside occur depending on reasons such as the operation type, characteristics of the ships, and properties of the used equipment, competency of terminal workers, environmental conditions and lack of security rules [1].

The risks encountered during berthing and mooring operations similar to each other for all terminal types. During the berthing operations, ship may strike something fixed such as a navigation aid or a bridge structure or a berth, or other mooring ships alongside the berth. This event that is defined as contact may cause harm to human life and environment and property damage. This event is grouped as the subheadings of contact to berth, contact to ship and contact to quay crane in the following analysis. Moreover, breaking of mooring rope is very damaging event as an uncontrolled force. Therefore, it is most dangerous for persons worked in the area. In addition to, there are work accident risks on deck such as hatch cover problems, falling of ship crane.

There are the risks of a failure of lifting equipment and falling containers during loading and unloading operations at the container terminal. Wrong lashing applications may cause various accidents such as falling of the containers to the sea, further, during lashing operations workers may fall from height. While the leave of the ship, ship may bump arms of SSC. During operation, quay cranes or a moving container may crush workers. Reverse maneuvering without seeing the back, and turning and changing lanes on the quay of the transport vehicles may causeto dangerous. This event creates the risk of work accident on berth.

At the bulk cargo terminals, a failures of handling equipment and hatch create a risk. There arethe risks of a failure of pipelines during operations at the liquid bulk terminals. During operations, hazard chemicals may exposure.

At the Ro-Ro terminals, a failures of Ro-Ro bridges or vessel ramps may cause to harm to human life because it results in falling to sea. Some events such as reversing vehicles on Ro-Ro decks and falling of car from transporters cause to dangers.

Not obeying to security rules and carelessness during quayside operations may cause to work accidents. In addition to these risks occurring during operations, weather conditions affect operations and cause to dangers.

\section{THE ANALYSIS OF ACCIDENTS AT THE QUAYSIDE OPERATIONS}

According to terminal types, incidents occurring in the Turkish ports are analyzed for the period 2009- 2015. Incidents, its reasons and effects on human life and environment in this period are given the following tables. Used statistics were handled from the Marine Causalities and Incidents statistics of Turkey Ministry of Transport, Maritime Affairs and Communications [5]. Incidents are investigated by divided into three groups; berthing and mooring operations, loading/ unloading operations and while waiting at the berth.

Table 1 shows incidents of the dry bulk terminals. The number of incidents occurring at the dry bulk terminal are 43. $63 \%$ of these incidents have occurred during berthing and mooring operations. $41 \%$ of accidents occurring during berthing and mooring operations are the group of contact to ship. However, the most of life losses have occurred during loading and unloading operations, $44 \%$ of accidents in these operations were resulted in life losses. For example, while a quay crane performs handling operations, it had crashed a stevedore in the same way, a stevedore had been hooked a sling in this period. These accidents have been grouped as work accident on berth in the tables. And a stevedore had jammed to the hatch cover of ship. This accident has been grouped as work accident on deck in the tables. Environmental pollution occurred in the one of accidents at the dry bulk terminal in this period. The first three reasons of accidents for berthing and mooring operations are the failures of maneuvering, machine and navigation. The first three reasons of accidents for loading unloading operation are failure of stevedore, failure of loading and failure of technical on ship. $57 \%$ of incidents occurred while ship is waiting at the berth arise from extreme weather conditions.

Table 2 shows incidents of container terminals. The number of incidents occurring at the container terminal are $7.71 \%$ of these accidents have occurred during berthing and mooring operations. $60 \%$ of accidents occurring during berthing and mooring operations are the group of contact to berth. $20 \%$ of accidents occurring during berthing and mooring operations were resulted in life losses. Reasons of accidents occurring during loading- unloading operations are the failures of stevedore and loading. For exempla, after a terminal transport vehicle delivered container to quay carne, due to reverse maneuvering it had fall to sea. This accident has been grouped as work accident on berth in the table. 
Table 3 shows incidents of liquid bulk terminals. During loading-unloading operations, incidents of fuel leakage and fire have occurred. And environmental pollution has taken place.

Table 4 shows incidents of Ro-Ro/Passenger terminals. The number of incidents occurring at this terminal are 16. $69 \%$ of these accidents have occurred during berthing and mooring operations. $64 \%$ of accidents occurring during berthing and mooring operations are the group of contact to berth. $80 \%$ of accidents occurring during loading and unloading operations were falling of car into sea. Life losses have occurred in the $20 \%$ of these accidents.

Table -1: Incidents of Dry Bulk Terminals.

\begin{tabular}{|c|c|c|c|c|c|c|}
\hline 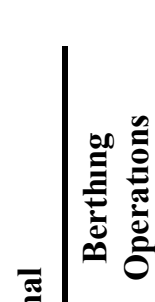 & INCIDENTS & $\%$ & REASON & $\%$ & CONSEQUENCE & $\%$ \\
\hline \multirow{6}{*}{ O气 } & - Contact to Ship & 41 & - Failure of Maneuvering & 33 & - Commercial Losses & 67 \\
\hline & - Contact to Berth & 22 & - Failure of Machine & 26 & - Injured & 11 \\
\hline & - Grounding & 22 & - Failure of Navigation & 18 & - Losses of Life & 7 \\
\hline & - Contact to Quay Crane & 11 & - Extreme Weather Condition & 15 & & \\
\hline & - Work Accident (on deck) & 4 & - Mooring Ropes Problems & 4 & & \\
\hline & & & - Failure of Technical on Ship & 4 & & \\
\hline & - WorkAccident (on berth) & 23 & - Failure of Stevedore & 33 & - Losses of Life & 44 \\
\hline & - Fire & 22 & - Failure of Technical on Ship & 23 & - Commercial Losses & 22 \\
\hline in $\stackrel{90}{=}$ & - Cargo Shifts & 11 & - Failure of Loading & 22 & - EnvironmentalPollution & 11 \\
\hline E亏 & - Contact to Berth & 11 & - Extreme Weather Condition & 11 & & \\
\hline 퓽 을 & - Work Accident (on deck) & 22 & - Mooring Ropes Problems & 11 & & \\
\hline 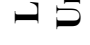 & - Capsizing & 11 & & & & \\
\hline & - Grounding & 43 & - Extreme Weather Condition & 57 & - Commercial Losses & 57 \\
\hline$\stackrel{00}{\equiv}$ & - Listing & 29 & - Not knowing & 43 & - Losses of Life & 14 \\
\hline & - Contact to Ship & 14 & & & & \\
\hline$z$ & - Fire & 14 & & & & \\
\hline
\end{tabular}

Table -2: Incidents of ContainerTerminals.

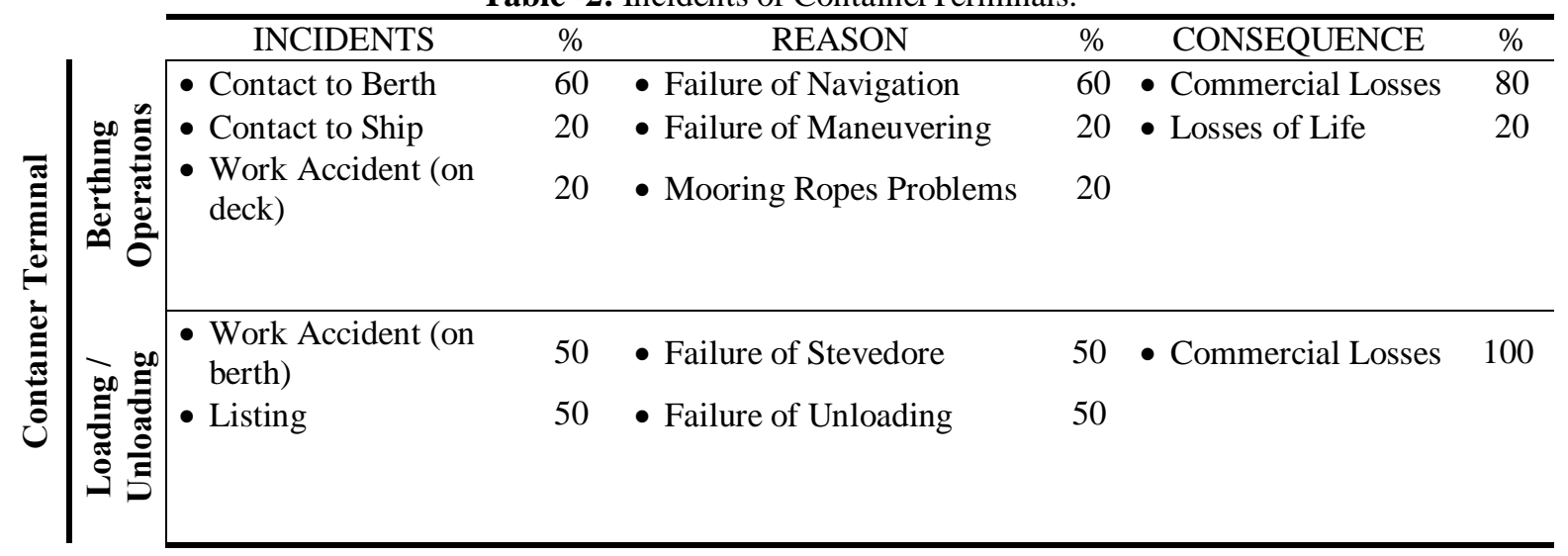

Table -3: Incidents of LiquidBulk Terminals.

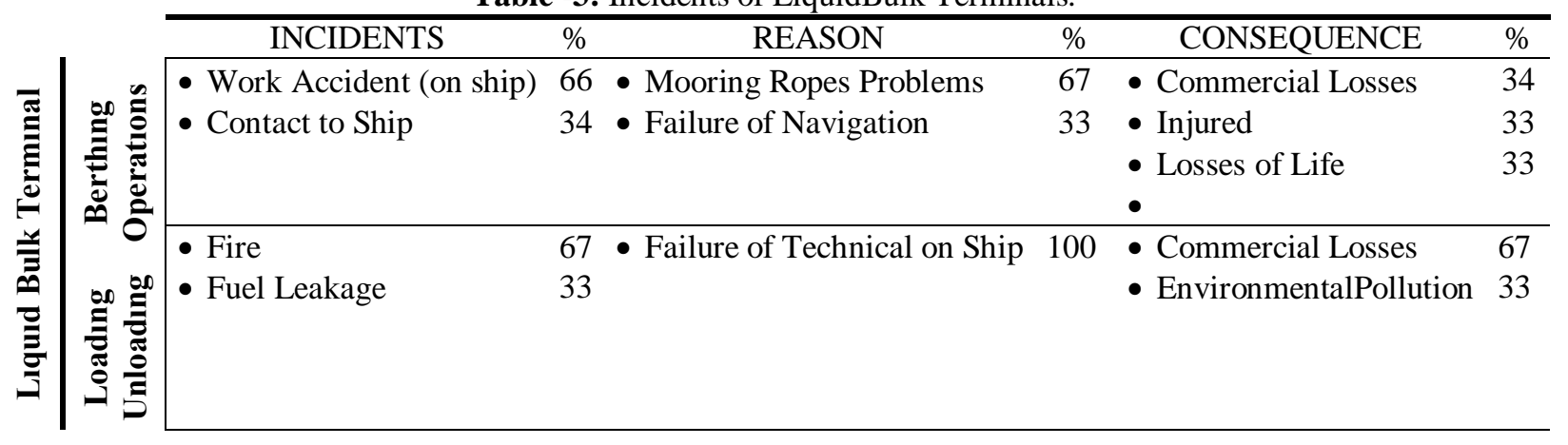


Table -4: Incidents of Ro-Ro/PassengerTerminals.

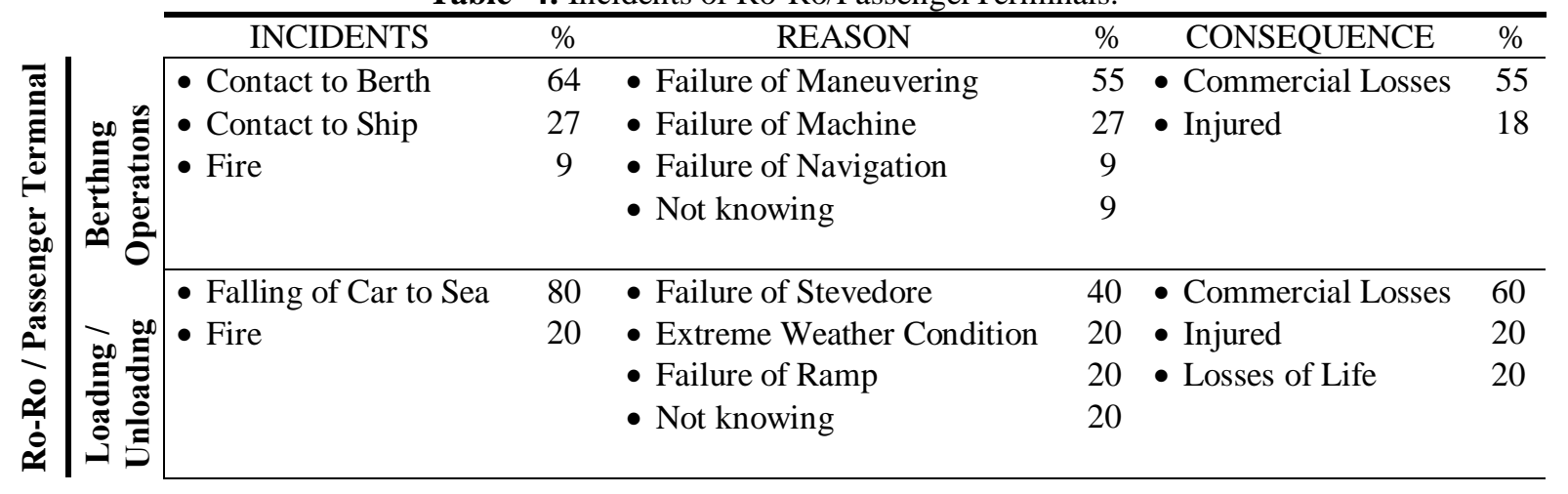

Weather conditions have created an important risk in the quayside operations for this period. Especially a crucial part of the accidents occurring at the quayside operations were taken place by strong winds.

\section{CONCLUSIONS}

Most of accident have occurred at the dry bulk terminals in this period. $61 \%$ of all accidents at the dry bulk terminals, $23 \%$ of all accidents at the Ro-Ro/passenger terminals, $10 \%$ of all accidents at the container terminals, and $6 \%$ of all accidents at the liquid bulk terminals have occurred in this period.

Most of accidents have occurred during berthing and mooring operations, however most of life losses have occurred during loading and unloading operations generally. The accident types encountered during the loading unloading operations are work accidents and cargo shifts arising from the failures of stevedore and loading generally.

In this context, the terminal administration must determine the risks according to the characteristics of terminal and carry out the necessary works to prevent these. Security rules must be obeyed maximally and operations must be carried out with care. Otherwise, the results such as property damage and operation delay with the best possibility, and seriously losses of life and environment pollution became inevitable.

\section{REFERENCES}

[1].Emecen Kara E.G., Kaçmaz E., (2015), "Determining the Risks in Maritime Container Terminal Operations: Health and Safety Applications", International Conference on Engineering and Natural Sciences (ICENS 2015), Skopje, Macadonia, 15-19 May 2015, pp 15-20.

[2].HSE, A Quick Guide to Health and Safety in Ports, [Online]. Available: http://www.hse.gov.uk/, 2011.

[3].Emecen Kara E.G., Kara G., and Bamyacı M., "Productivity Measurement of Maritime Container Terminals", 6th International Logistics Supply Chain Congress, Istanbul, Turkey, November 6-7, pp.453-457, 2008.

[4].Emecen Kara E.G., and Heydarova F., "Container Terminal Operations and Operations Planning"", 6th
International Logistics Supply Chain Congress, Istanbul, Turkey, November 6-7, pp.433-439, 2008.

[5].Republic of Turkey Ministry of Transport, Maritime Affairs and Communications, Maritime Causalities and Incidents Statistics, Available online: http://aakkm.udhb.gov.tr/ (2015). 